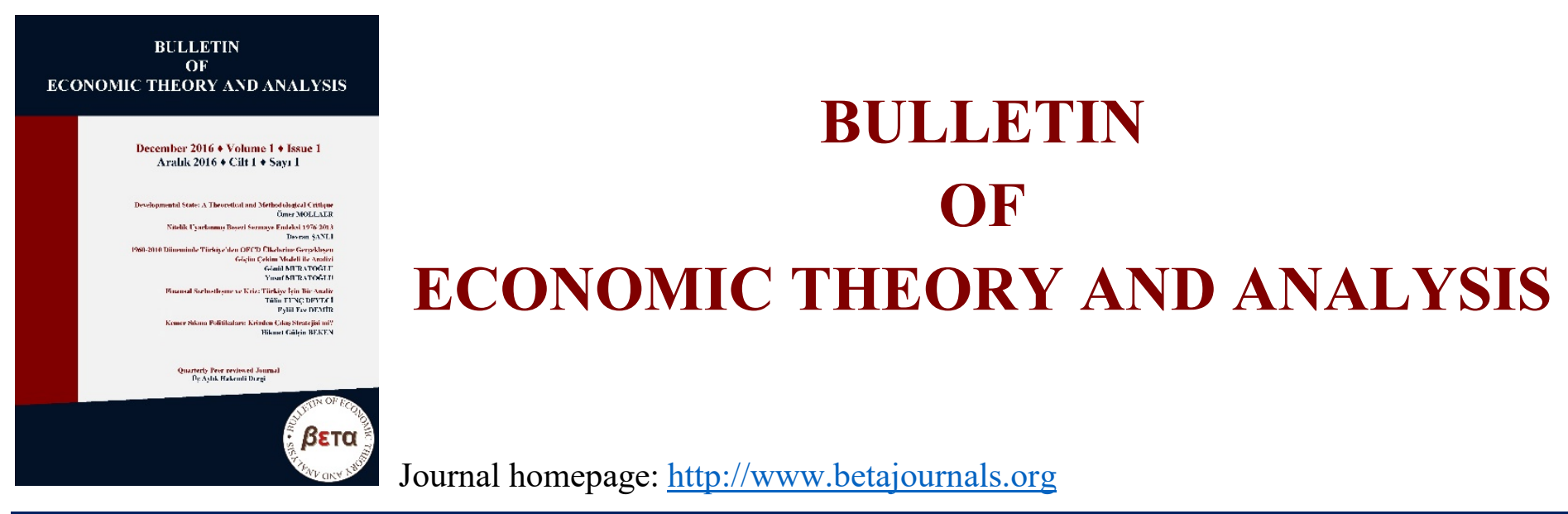

\title{
Dış Ticaret-Ekonomik Büyüme İlişkisi: İran Örneğinde Bir Nedensellik Analizi
}

\section{Bayram Ata \& T. Mesut Eren}

To cite this article: Ata, B. \& Eren, M., T. (2017). Diş Ticaret-Ekonomik Büyüme İlişkisi: İran Örneğinde Bir Nedensellik Analizi. Bulletin of Economic Theory and Analysis, 2(4), 329-346.

Received: 13 Dec 2017

Accepted: 30 Mar 2018

Published online: 10 May 2018

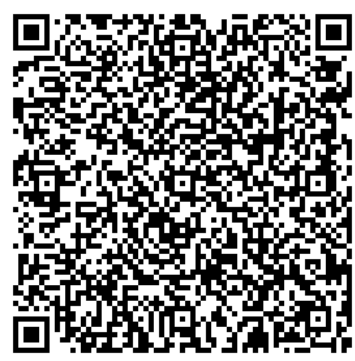




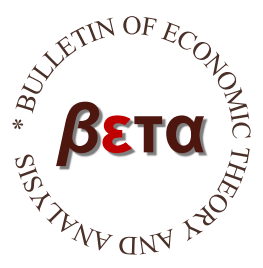

\title{
Bulletin of Economic Theory and Analysis
}

Volume II, Issue 4, pp. 329-346, 2017

http://www.betajournals.org

\section{Dış Ticaret-Ekonomik Büyüme İlişkisi: İran Örneğinde Bir Nedensellik Analizi $^{1}$}

\author{
Bayram Ata ${ }^{\mathrm{a}}$ \\ T. Mesut Eren ${ }^{b}$
}

a Öğrenci, Yüksek Lisans, İstanbul Aydın Üniversitesi, Sosyal Bilimler Enstitüsü, Uluslararası İktisat, İstanbul, TÜRKIYYE

b Doç. Dr. Marmara Üniversitesi, AB İktisadi Ana Bilim Dalı, İstanbul, TÜRKIYYE

\section{ÖZ}

Bu çalışmada, İran'ın ekonomik yapısı kısaca analiz edilmiş ve ekonomik büyüme üzerinde rol oynayan faktörlerden diş ticaret incelenmiştir. Yapılan analizde ülkenin dış ticaretinin ekonomik büyümesini ne yönde etkilediği incelenmiştir. Bunun için bu çalışmada Granger nedensellik analizi kullanılmıştır. Yapılan nedensellik testi sonucunda hem ithalatın büyümenin nedeni olduğu ve hem de ihracatın büyümenin nedeni olduğu sonucuna varılmıştır. Yapılan analiz sonucunda İran'ın ihracat ve ithalatının ekonomik büyümesini etkilediği sonucuna varılmıştır.
Anahtar Kelimeler Ekonomik büyüme, İran, Granger Nedensellik Testi, Ithalat, İhracat, Diş Ticaret

\section{JEL Kodu} C100, F100, O40

CONTACT Bayram ATA $\bowtie$ bayram90ata@gmail.com $\Xi^{\prime}$ Yüksek Lisans Öğrencisi, İstanbul Aydın Üniversitesi, Sosyal Bilimler Enstitüsü, Uluslararası İktisat, İstanbul, TÜRKİYE

1 “Ortadoğu Ülkelerinde Ekonomik Kalkınma; İran Ve Suudi Arabistan Örneği” adlı yüksek lisans tezinden türetilmiştir. 


\section{The Relation between Foreign Trade and Economic Growth: A Causality Analysis on the Case Iran}

\begin{abstract}
In this paper, we have investigated briefly the economic structure of Iran and assessed the effects of foreign trade as one of the most important factor on economic development. We used the Granger causality analysis to examine whether Iran's foreign trade is related with its economic growth. The results show that both import and export are granger cause of economic growth. To conclude we can say that the results prove a certain causality between Iran's foreign trade and its economic development.
\end{abstract}

Keywords

Economic Growth, Iran, Granger Causality Test, Import, Export, Foreign Trade

JEL Classification C100, F100, O40

\section{Giriş}

Ortadoğu'nun benzersiz ekonomik yapısı bazı faktörlerin olağanüstü bir kombinasyonudur (Direnizci, 2005:30). Ortadoğu'ya yönelik geliştirilen stratejileri sadece petrol unsuruna bağlamak mümkün değildir. Konu, Ortadoğu'nun ekonomi merkezli siyasi tarihi açısından değerlendirildiğinde, petrolün tek başına yeterli olmadığı görülmektedir. Bugün Ortadoğu olarak adlandırılan bölge, antik dönemlerden bu yana tarım potansiyeli ve ticaret aktarım hattı olarak önemli bir konumda yer almaktadır. Dünya ana kıtası üzerindeki bütün ulaşım ve ticaret yollarının Ortadoğu ile doğrudan veya dolaylı olarak bağlantı içinde olması, bölgeyi ekonomi eksenli politikaların merkezi haline, getirmekte (Dural, 2007:7). Gerçekleştirilen petrol üretimi buna bağlı olarak gerçekleşen ihracat rakamları ülkelerin ekonomik açıdan kalkınmaları bakımından en büyük etkendir. Ayrıca bu ülkelerde sadece petrol üretimi ve satışı yapılmamaktadır. Yeraltı kaynaklarından elde edilen petrolün işlenmesi aşamasında elde edilen diğer yağ ve yakıtlarda ülke ekonomisine büyük katkı sağlamaktadır. Bu durum, dünyadaki güç odağı olarak kabul edilen ülkelerin dikkatlerini çekmektedir. Böylelikle tüm gözler bu bölge üzerine toplanmaktadır.

Tarihte güçleriyle kendilerini kabul ettiren devletlerin bölge ile ilgilenmelerinin temelinde, Ortadoğu'nun coğrafi değerinin, ticari olanaklarının ve doğal kaynaklarının kullanımı düşüncesi yatmıştır. Bu doğrultuda; Ortadoğu, tarihi süreç içerisinde İngilizlerin, Fransızların, Rusların, Osmanlıların ve son dönemlerde de ABD ile Çin gibi kıta devletlerinin ilgisini çekmiştir. Dünya petrol kaynaklarının büyük bir kısmı yaklaşık üçte ikisi bu bölgede yer almakta ve bu kaynaklardan 
çıkan petroller Batı Avrupa ekonomisi için hayati önem taşımaktadır. II. Dünya Savaşı öncesi ağırlıklı olarak siyasal alanda mücadele eden büyük devletler, Ortadoğu'da kendi petrol şirketlerini kurarak ürettikleri petrolle dünya siyasetine yön vermeyi hedeflemişlerdir. İkinci Dünya Savaşı'nın ardından petrolün stratejik bir unsur olarak bölgesel ve uluslararası gelişmelerde önem kazanması tarih sahnesinde yeni bir dönemin başlangıcının da habercisi olmuştur. Savaş sonrasında başta ABD ve İngiltere olmak üzere diğer batılı devletler çeşitli oyunlarla pay alma yarışına girmişlerdir. Söz konusu devletlerin petrol unsurunu kullanmak suretiyle bölgedeki siyasi gelişmeleri denetleyerek genel siyasete yön verdikleri görülmüsştür (Mazman, 2008).

Özellikle Suudi Arabistan, İran ve Irak petrol rezervleri açısından hem bölgesel anlamda hem de küresel anlamda dünyanın en zengin rezervlerine sahip ülkelerindendir. Suudi Arabistan ve Irak’ta rezerv zenginliklerinin yanında ayrıca üretimin gerçekleştiği sahalardaki kuyuların sığ olması petrol piyasası için önemli olan varil başına üretim maliyetini de düşürmektedir (Akça, 2013).

Bu çalışmada en önemli bölge aktörlerinden olan İran İslam Cumhuriyeti kısa adıyla İran ele alınacaktır. Petrol ticareti, İran'ın dış ticaretinin en önemli unsurunu oluşturmaktadır. Bu çalışmada, İran'ın petrole bağımlı ticaretinin ekonomik büyümesi üzerinde bir etkisinin olup olmadığı sorusuna cevap aranacaktır. Literatürde İran özelinde yapılmış çok az sayıda çalışma vardır. Bunun en önemli nedeni İran ile ilgili bilgi kaynaklarına ve istatistiklere erişimin son derece kısıtlı olmasıdır. Buna rağmen dış ticaretin büyüme üzerindeki etkisinin, İran için sayısal veriler ve bir nedensellik analizi yardımıyla test edilecek olması bu çalışmayı önceki çalışmalardan ayıran en önemli özelliğini oluşturmaktadır.

Çalışmanın ikinci bölümü İran ekonomisinde petrolün rolü ve bununla ilgili sayısal veriler değerlendirilmekte olup, temel makroekonomik değişkenler şekil ve tablolar yardımıyla tartışılmaktadır. Üçüncü bölümde hem İran konusunda hem de Granger b-nedensellik analizi ile ilgili literatür taraması yer almaktadır. Dördüncü bölümde analizde kullanılan model tanımlanmış, beşinci bölümde İran'ın ithalat ve ihracatı ile ekonomik büyümesi arasında Granger nedensellik bağı olup olmadığı araştırılmıştır. Çalışmanın altıncı ve son bölümünde çıkan sonuçlar değerlendirilmiş ve tartışılmıştır.

\section{2. İran Ekonomisinin Değerlendirilmesi}




\section{1. İran Ekonomisinde Petrolün rolü}

Birinci Dünya Savaşından sonra birçok Ortadoğu ülkesi birer sömürge ülkesi haline gelmiştir. Son yıllarda her ne kadar bu ülkeler bağımsızlıklarını tamamen ilan etmiş olsalar da bu etki hala devam etmektedir.

İkinci Dünya Savaşı'ndan sonraki dönemde yapılan bilimsel çalışmalarda ve uluslararası siyasette giderek kullanımı yaygınlaşan "Ortadoğu”, tarihsel süreçte birçok uygarlığa ev sahipliği yapmıştır. Bölge farklı etnik, dini ve kültürel yapıların kaynaşmasına sahne olmuştur. Ortadoğu'nun adı gibi sınırları ve kapsamı da kesin olarak belli değildir. Ortadoğu'nun sınırlarının net olmaması bölgenin coğrafi anlamda tanımlanmasını da zorlaştırmaktadır (Lewis, 1964:41). Ortadoğu tarihte gerek ekonomik olarak gerekse bilim ve sanat alanlarında yerini hızlıca alırken, günümüze gelene kadar bu yerlerini kaybetmişlerdir. Bu alanlardaki yerlerini kaybetme sebepleri ise tarihsel süreçte yaşanan özellikle siyasi sorunlar olmuştur. Bazı ülkelerin ikinci dünya savaşı sonrası egemenliklerini tamamen ilan edememesi, bazı ülkelerinse gerek komşu ülkelerle ikili ilişkilerde yaşadıkları sorunlar gerekse ülke içindeki hem dini hem de siyasi sorunlar Ortadoğu ülkelerinde gerileme yaşanmasına neden olmuştur. Ancak bu gerileme ülkelerin doğal zenginlikleri sayesinde ekonomik alanı diğer alanlara göre daha az etkilemiş̧tir.

İran, OPEC tarafından yayınlanan raporlara göre dünyanın ikinci en büyük petrol üreticisidir. Dünya petrol rezervlerinin yüzde dokuzluk kısmı ve doğalgaz rezervlerinin yüzde on beşlik kısmı İran ülke sınırları içerisinde yer almaktadır. İran yüz otuz milyar varil kanıtlanmış petrol rezervine sahiptir. İran'ın ham petrol rezervlerinin önemli bir bölümü Irak sının yakınındaki Kuzistan'da yer almaktadır. İran toplamda 40 kadar petrol alanına sahiptir ve petrol alanlarının 27 tanesi karada bulunmaktadır. İran 2006 yılında günlük petrol üretimi 4,2 milyon varildir (3,9 milyon varili ham petrol). İran 2006 yılında Hazar denizinde yeni petrol kuyuları açma çalışmalarına başlayarak petrol üretimini arttırmayı hedeflemiştir (Çalış, 2006:15). 2014 yılına gelindiğinde açılanan üretim miktarı 3 milyon 121 bin varil ham petroldür. Daha öncede belirttiğimiz gibi ülkede tutulan ekonomik kayıtlar dış devletlerle tamamen paylaşılmadığı için 2015 ve 2016 yılı üretim miktarları net olarak bilinmemektedir. OPEC tarafindan hazırlanan raporlarda ise Ortadoğu ülkelerinin genelindeki mevcut üretim miktarlarının tamamı yer almakta ülke bazında belirtilmemektedir. 
İran, Rusya'dan sonra dünyanın en büyük doğal gaz rezervine sahiptir. İran'ın doğal gaz rezervleri tek bir bölgede değildir. Bu rezervler büyük ölçüde geliştirilmemiş sahalarda yer almaktadır. Buna bağlı olarak ülkenin doğal gaz konusunda büyük bir potansiyeli bulunmaktadır. Artan iç tüketime rağmen İran aynı zamanda önemli bir doğal gaz ihracatçısıdır (İran İslam Cumhuriyeti Ülke Raporu, 2008:7). İran 2005 y1lında 87,0 milyar m3 doğal gaz üretmiştir. O dönemde İran toplam enerji ihtiyacının yüzde 44'ünü doğal gazdan karşılamaktaydı (Direnizci, 2005:30). 2015 yılın 3 milyon 665 bin varil petrol çıkaran İran, 2016'nın ilk yarısında bu rakamı 3,8 milyon varil seviyesine çıkarmıştır. Ülkenin hedefi ise 4 milyon varil düzeyi ve üzeridir.

İran'1n güneyinde bulunan ve 8-13 trilyon m3 doğalgaz rezervi olduğu tahmin edilen Güney Pars Sahası'nın geliştirilmesine yönelik projenin bazı aşamaları, ihraç edilmek üzere sıvılaştırılmış doğalgaz üretimine ayrılmıştır. Bu saha yabancı sermayeye açılmış ve aşamalar halinde çeşitli uluslararası konsorsiyumlar ile doğalgaz kaynaklarının araştırılması ve geliştirilmesi yönünde çalışmalara hız verilmiştir. Güney Pars doğalgaz sahası Basra Körfezinde İran ile Katar arasında paylaşılmaktadır. Bu bölge "off-shore” bir bölge olarak karşımıza çıkmaktadır. İran, mevcut zengin doğal gaz rezervlerine rağmen üretim açısından on iki ülke arasında sekizinci sırada bulunmaktadır. İran aynı zamanda, Irak ile petrol konusunda işbirliğini geliştirmektedir. Geçmişte yaşadıkları siyasi krizleri bir kenara bırakarak iş birliği yapma hazırlığındalar. Böyle bir atılımın diğer devletlere olumlu örnek olması söz konusudur. Ayrıca bu işbirliğinin başarılı bir şekilde sonuçlanması ortak çıkarlara sahip ancak siyasi anlaşmazlık yaşayan, birbirlerini rakip olarak gören diğer ülkelere örnek teşkil etmesi beklenmektedir. İran'ın Abadan Rafinerisinden yararlanabilmesi ve bu sayede günde 250,000 varil petrol taşıma kapasitesine sahip olan mevcut petrol boru hattının 6 mil kadar daha uzatılması bağlamında çalışmalar gerçekleştirilmektedir. 2015 yılının Ocak ayında Tahran ile gerçekleştirilen görüşmelerde Irak Petrol Bakanı Adil el-Mehdi'de İran ve Irak'ın ortak sahalardan petrol ve doğal gaz çıkarma konusunda ve ayrıca ortak kaynaklardan yararlanma hususunda Tahran-Bağdat işbirliğinin diğer ülkeler için bir örnek olarak kullanılabileceği kayıtlara geçmiştir (İran Ülke Bülteni, 2015).

Tablo 1'de OPEC tarafindan yayınlanan rapora göre hazırlanmış olan dünya genelindeki kanıtlanmış petrol ve doğalgaz rezervlerinin bulunduğu ülkeler yer almaktadır. Ayrıca bu tabloda bu rezervlerin miktarı yer almaktadır. 


\section{OPEC Raporu}

\begin{tabular}{lcc}
\hline \hline & Kanıtlanmış Petrol Rezervleri & \\
Ülke & Sira & Rezerv (milyar varil) \\
\hline Venezuela & 1 & 299,9 \\
Suudi Arabistan & 2 & 266,6 \\
Kanada & 3 & 175,0 \\
İan & 4 & 157,3 \\
\hline \hline & Kanıtlanmış Doğalgaz Rezervleri & \\
Ülke & Sira & Rezerv (tr. küb. m.) \\
\hline Rusya & 1 & 49,5 \\
İran & 2 & 34,0 \\
Katar & 3 & 24,5 \\
\hline
\end{tabular}

Not. OPEC'den alınmıştır.

\section{2. İran İslam Cumhuriyeti’nin Ekonomik Yapısı}

İran, Ortadoğu ve Kuzey Afrika Bölgesi’nde yer alan Suudi Arabistan'dan sonra ikinci büyük ekonomidir. Ülkenin ekonomisi neredeyse tamamen petrol ihracatına bağlıdır (İran Ülke Bülteni, 2015). Şekil 1'de 1997-2016 dönemine ait GSYİH artış oranları verilmiştir.

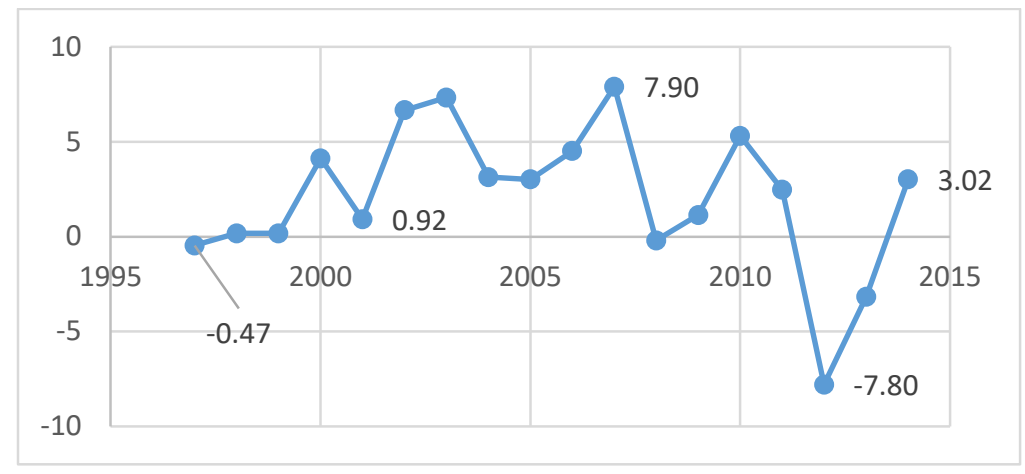

Şekil 1. İran - Gayri Safi Yurtiçi Hâsıla artış hızı \% (GSYİH) (1997-2016). The World Bank, http://databank.worldbank.org/data/home.aspx 'den alınmıştır.

Şekil 1'de görüldüğü üzere, İran'ın Gayri Safi Yurtiçi Hâsıla artış verileri yıllara göre sürekli değişkenlik göstermektedir. Yirmi yıllık GSYİH ortalama artış hızı \%2,12 olurken 2012 ve 2013 yıllarında negatif eğilim göstermiştir. 
Ülkede yerel ve uluslararası bankalara uygulanan yaptırımlar nedeniyle ülke 2011 y1lında 541 milyar dolar olan İran'ın GSYİH'sı, 2012 yılına gelindiğinde 398 milyar dolara düşerken, bu rakam, 2013 yllında ise 367 milyar dolara gerilemiştir (İran Ülke Bülteni, 2015).

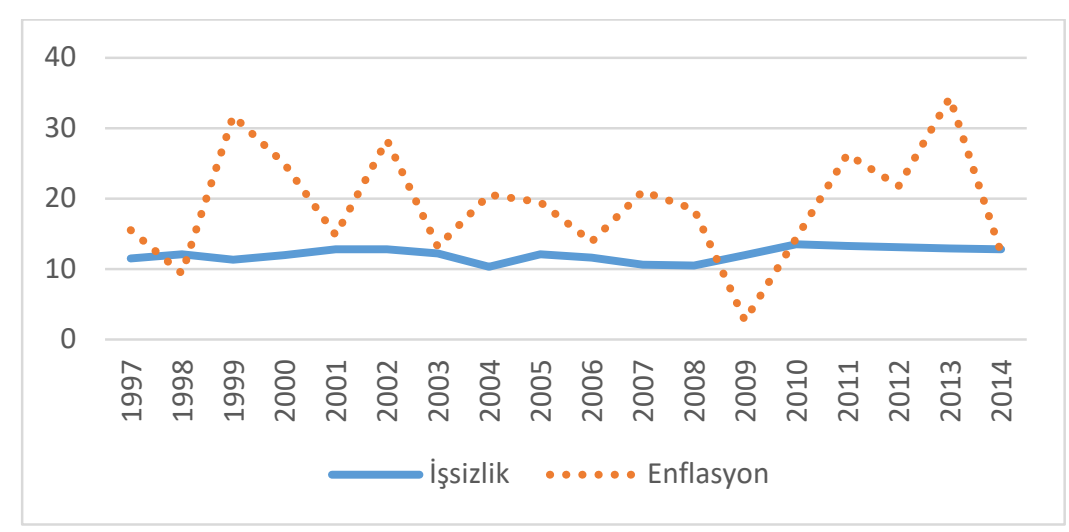

Şekil 2. İran - Enflasyon ve İşsizlik Oranı Karşılaştırması (1997-2015). The World Bank, http://databank.worldbank.org/data/home.aspx 'den alınmıştır.

Şekil 2'de görüldüğü üzere İran'ın yaklaşık son 20 yıllık işsizlik verilerini gözlemlemekteyiz. Bu veriler doğrultusunda İran'ın 2008 yllında yaşanan küresel krizden etkilendiğini buna bağlı olarak işsizlik oranında artış olduğunu söylemek mümkündür. Ayrıca İran'ın işsizlik verileri durağan bir seyir izlemektedir. Çok küçük yüzdelik oranlarla artış ve azalış göstermiştir. Turan ve Özarı 2015 yılında yapmış oldukları çalışmada başlıca dünya devletlerinin, özellikle de bölgelerin verileri incelenerek işsizlik oranı ile enflasyon oranı arasında ters yönlü bir ilişki olduğundan bahsetmişlerdir (Turan ve Özarı, 2015: 155-177). Ancak dünya veri bankasından alınan ve İran devletine ait bu makroekonomik değişkenlere ait verilere baktığımızda söz konusu durumun İran için geçerli olmadığını gözlemliyoruz. İran'ın son yirmi yıllık verisine baktığımızda enflasyon oranında ülke içerisinde ve komşu ülkelerle yaşanan siyasi olaylara bağlı olarak sürekli olarak bir dalgalanma gözlemlenmektedir. Ancak işsizlik oranına bakıldığında ise bu süreçte sürekli olarak benzer ya da çok küçük oranla farklılık gösterdiğini gözlemlemek mümkün. Bunun nedeni ise ülke ekonomisinin bağlı olduğu doğal kaynaklardır.

İran'ın ihracat kalemleri arasında en önemlileri ham petrol ve doğalgazdır. Ülkenin toplam ihracat gelirinin yüzde seksenlik kısmını petrol ve doğalgaz ihracatı oluşturmaktadır. Bu oran dünya genelindeki ham petrol fiyatlarına bağlı olarak artış ve azalış göstermektedir. Tüm bunların 
yanı sıra çok küçük miktarlarda da olsa petrol dışında ihracat da gerçekleşmektedir. Petrol ve doğalgaz dışında gerçekleşen ihracat kalemleri şu şekildedir; halı, fıstık, deri, kuru meyve ve sebzeler, havyar ve metallerdir (Direnizci, 2005: 30). Petrol ve doğalgaz ülke ekonomisi açısından en önemli yeri tutmaktadır. Tablo 2'de 2011-2014 dönemine ait İran diş ticaret verileri yer almaktadir.

Tablo 2

Iran Dış Ticaret Verileri

\begin{tabular}{lllll}
\hline \hline & 2011 & 2012 & 2013 & 2014 \\
\hline İhracat (milyon \$) & 112,788 & 145,518 & 98,033 & 93,015 \\
İthalat (milyon \$) & 75,458 & 77,729 & 67,058 & 60,047 \\
Petrol Üretimi (1000 varil/gün) & 3,576 & 3,740 & 3,576 & 3,121 \\
Petrol İhracatı (milyon \$) & 90,191 & 118,861 & 68,135 & 64,789 \\
\hline
\end{tabular}

Not. İran Ülke Bülteni (2015)'nden alınmıştır.

İran'ın 1997-2015 yılları arasındaki ithalat ve ihracat rakamlarının GSYİH'ya oranı Şekil 3'te verilmiştir.

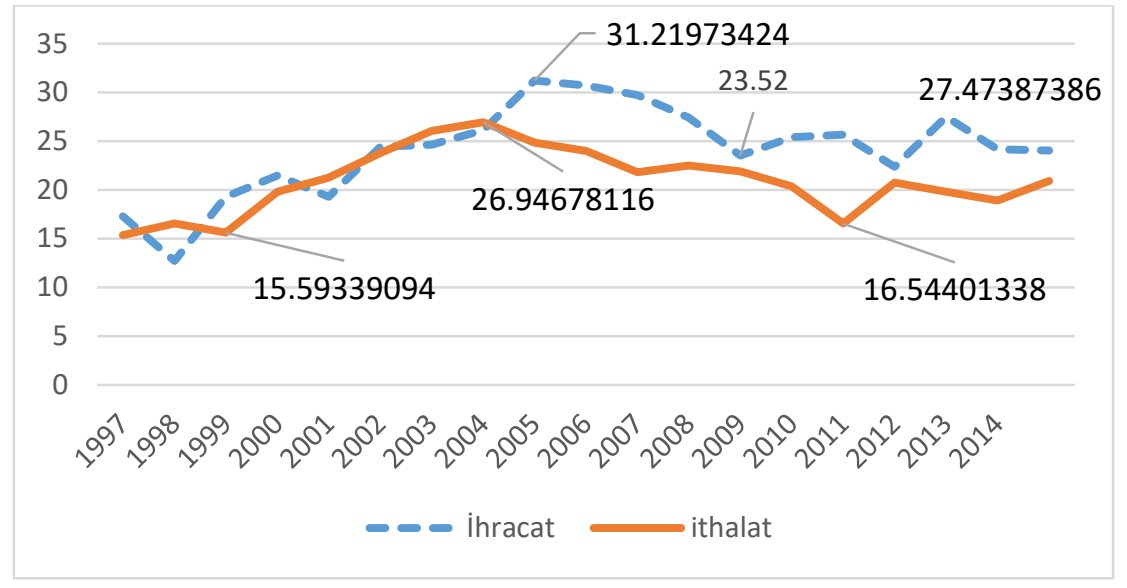

Şekil 3. İran - İthalat ve İhracat rakamlarının GSYİH'ya Oranı (1997-2015). The World Bank, http://databank.worldbank.org/data/home.aspx 'den alınmıştır. 
Şekil 3'te 1997-2015 yıllarında İran'1n ithalat ve ihracat rakamlarının GSYİH'ya oranı verilmiştir. Verilen bu rakamlar incelendiğinde ithalatta bu oran ortalama 20,92 iken, ihracatta 24,05'tir.

İran 1996 y1lında Dünya Ticaret Örgütü'ne (DTÖ) üyelik başvurusunda bulunmuştur. Ancak bu başvuru Amerika Birleşik Devletleri'nin engeline takılarak başvurusu askıya alınmıştır. Dünya geneline baktığımızda İran, Dünya Ticaret Örgütü'ne üye olmayan en büyük ekonomidir. İran'ın yapmış olduğu nükleer anlaşma sonrasında Dünya Ticaret Örgütü’ne tam üye olması beklentisi artmıştır.

İran'da dış ticaret konusunda yaşanan en büyük sorun ülkenin hali hazırda kullanmış olduğu bir gümrük mevzuatı bulunmamasıdır. Aynı zamanda bu ülkede bankacılık ve hukuk sistemi de tam anlamıyla oturmamıştır. Tüm bu eksikliklerden dolayı ülkeye gerçekleştirilen ithalat maliyetleri çok yüksektir ve süreç çok uzamaktadır.

\section{Literatür Taraması}

Bu bölümde, Granger nedensellik analizi ile yapılan ilgili çalışmalara, ekonomik büyümeyi etkileyen değişkenler üzerine yapılan bazı çalışmalara ve İran ile ilgili kısıtlı literatüre bakacağız. 2003 yılında Karaca tarafından yapılan bir çalışmada, 1987-2002 yıllarına ait Türkiye'nin verileri ile enflasyon, ekonomik büyüme arasındaki ilişki analiz edilmiştir. Yapılan nedensellik analizi sonucunda, çalışılan dönemde enflasyon oranında meydana gelen her 1 puanlık artış sonucunda, ekonomik büyüme oranının 0,37 puan düşüş yaşadığg tespit edilmiştir. Özetle iki değişken arasında çalışılan dönemde negatif yönlü ilişki tespit edilmiştir.

2003 yılında yapılan bir diğer çalışmada Valadkhani, İran’’n 1968-2000 yılları arasında işsizliğin nedenlerini eşanlı denklemlerle incelemiştir. İşsizlik oranının hâsıla boşluğu ile ekonomik belirsizlik arttıkça arttığını yani aralarında pozitif ilişkinin bulunduğunu ancak işsizlik oranı ile yüksek büyüme oranları, reel yatırımlar ve enflasyon arasında negatif ilişki olduğunu saptamıştır.

2005 yılında Arısoy Türkiye’nin Kamu Harcamalarının Ekonomik Büyüme ile ilişkisini Nedensellik Modeli ve Keynesyen ekonometrik model ile analiz etmiştir. Yapılan analiz sonucunda kamu harcamalarının unsurlarına doğru ekonomik büyüme arasında tek yönlü bir nedensellik 
ilişkisi saptanmış ve ekonomik büyümenin kamu harcamalarını artıracağını öne süren Wagner Yasasını destekleyen sonuçlar elde etmiştir.

2008 yılında Oktayer ve Susam tarafından Türkiye'nin Kamu Harcamalarının Ekonomik Büyüme ile ilişkisini analiz etmişlerdir. 1970-2005 dönemine ait Türkiye’nin verileri kullanılarak yapılan analizin sonucunda kamusal yatırım harcamalarının ekonomik büyüme üzerinde pozitif yönlü bir ilişki olduğu sonucu elde edilmiştir.

2009 yılında Aktaş tarafından yapılan çalışma Türkiye'nin 1996-2006 verileri yardımıyla ihracat, ithalat ve ekonomik büyüme arasındaki ilişkiyi nedensellik analizi ile incelemiştir. Hata Düzeltme Modeline kullanılan çalışmada, yapılan analiz sonucunda ihracattan ithalata, ithalattan ihracata, büyümeden ihracata ve büyümeden ithalata doğru tek yönlü bir nedensellik ilişkisi olduğu elde etmiştir.

2010 yılında Genç, Değer ve Berber tarafından yapılan çalışmada beşeri sermaye, ihracatın ekonomik büyüme üzerindeki ilişkisine nedensellik analizi ile bakılmıştır. Yapılan analizde Türkiye'nin 1980-2007 dönemine ait veriler kullanılmıştır. Bu analiz sonucunda, Türkiye ekonomisinin ihracatında görülen yapısal değişime paralel olarak daha fazla beşeri sermayeye gereksinim duyduğu şeklinde sonuç elde edilmiştir.

2011 yılında Akal, Doğruyol ve Bilişli tarafından yapılan çalışmada Şanghay İşbirliği Örgütü Ve Türkiye-İran savunma harcamalarının 1988-2008 dönemine ait verileri nedensellik analiz ile incelenmiştir. $\mathrm{Bu}$ bağlamda yapılan çalışmada Şanghay İşbirliği Örgütü’nün kurulmasından sonra ve İran'ın gözlemci üye statüsünde bulunuyor olmasının Türkiye savunma harcamalarını artırıcı yönde etkili olduğu sonucu elde edilmiştir.

2011 yılında yapılan bir diğer çalışmada ise Zamanzadeh ve Mehrara, 1959-2007 yılları arasında İran'da bütçe açığı ve petrol harici cari işlemler açığı değişkenleri ile yaptıkları çalışmada VECM kullanılmış ve her iki değişken arasında uzun dönemli ilişki saptanmıştır. Daha sonra gerçekleştirilen Granger nedensellik analizinde ise her iki değişkenin de birbirinin nedeni olduğu sonucu elde edilmiştir.

2013 yılında Akıncı, Aktürk ve Yılmaz, OPEC ülkeleri ve bazı petrol ithalatı yapan ülkeler için ekonomik büyüme ve petrol fiyatları arasındaki ilişkiyi analiz etmişlerdir. Analiz sonucunda, petrol fiyatları ve ekonomik büyüme arasında anlamlı bir ilişki olduğu sonucu elde edilmiştir. 
2013 yılında Yardımcıoğlu ve Gülmez, OPEC ülkesi olan 10 ülkenin 1970-2011 dönemine ait verileri yardımıyla; Petrol Fiyatları ve Ekonomik Büyüme ilişkisini incelerken aynı zamanda da bu ülkeler için Hollanda Hastalığının varlığını araştırmışlardır. Yapılan çalışma sonucunda, petrol fiyatları ve ekonomik büyüme arasında anlamlı bir ilişki olduğu sonucu elde edilmiştir. Ayrıca bu ülkeler için Hollanda hastalığı riskinin varlığı tespit edilmiştir.

Berber (2013) ise İran ekonomisinin genel yapısı ve siyasi ikilemlerine dair bir izdüşüm vermeye çalışmıştır.

Turan vd. 2016 yılında yapmış olduğu çalışmada, Ortadoğu ülkeleri 1980-2013 yıllarına ait makroekonomik değişkenlerin verilerinin yardımıyla kümeleme analizi yapılarak gruplandırılmıştır. Bu çalışmada Ortadoğu ülkelerinde meydana gelen siyasi olaylara bağlı olarak zaman aralığı gruplara göre bölünmüştür. Yapılan analiz sonucunda ise bu ülkelerde yaşanan siyasi olayların ülke ekonomisine doğrudan etkide bulunduğu sonucu elde edilmiştir (Turan vd., 2016:143-165).

\section{Granger Nedensellik Analizi ve Model}

Granger nedensellik analizi, bir zaman serisinin başka bir zaman serisini tahmini olarak, kullanışıı olup olmadığının bir istatistiki hipotez sınamasıdır. Normalde, bağlanımlar, "sadece" ilintileri yansıtmaktadır. Ekonomik zaman serilerinin durağanlığı ise Dickey ve Fuller $(1979,1981)$ tarafından geliştirilen ve uygulamada yaygın bir şekilde kullanılan analiz yöntemlerinden yararlanılarak belirlenebilmektedir. Yapılan bu çalışmada kullanılan verilerin yani zaman serilerinin birim kök içerip içermediğini anlamak için ADF (Genişletilmiş Dickey-Fuller) testi kullanılmıştır. Ayrıca Serilerin durağanlık sınaması için Augmented Dickey-Fuller (ADF) testinde sabitsiz, sabitli ve trendli bir süreç izlenmektedir. Bu sürece göre, kullanılan seri trendli bir süreçte durağan hale gelir ise diğer süreçler izlenmeksizin bu değer esas alınmaktadır. Eğer kullanılan seri trendli süreçte durağan hale gelmemiş ise, sabitli süreçten geçer. Eğer bu süreçte de durağanlık sağlanamamış ise sabitsiz sınama yapılmaktadır. Bu süreç sonucunda seriyi durağan hale getiren değer ise baz alınmaktadır (Enders, 1995: 256-259).

Birim kök testi yardımıyla söz konusu serilerin kaçıncı dereceden durağan oldukları saptanır. Yapılan bu test sonucunda her iki seri de aynı dereceden durağan (bütünleşmiş) çıkıyorsa, 
bu ilişkinin gerçek bir ilişki olduğu ve regresyonun gerçek olduğu söylenebilir. Ayrıca bu serilere “eş bütünleşmiş seriler” adı verilir.

Bu çalışmada aşağıda bulunan formülasyon yardımıyla ADF birim kök testi hesaplanmıştır.

$$
\Delta Y_{t}=\beta_{1}+\beta_{1} t+\delta Y_{t-1}+\sum_{i=1}^{k} \alpha_{i} \Delta Y_{t-1}+\varepsilon_{t}
$$

Denklemde yer alan "k” değişkeni olarak ifade edilen gecikme uzunluğu, genelde Akaike veya Schwarz bilgi kriterleri kullanılarak hesaplanmaktadır. Bu çalışmada Schwarz bilgi kriteri kullanılmıştır. Daha sonraki aşamada ise yapılan uygulamalı ekonometrik çalışmalarda, zaman serileri arasındaki nedensellik ilişkilerinin tespit edilmesi için genellikle Granger (1969) tarafından geliştirilen Granger nedensellik analizi kullanılmaktadır. X ve Y olmak üzere iki değişkene sahip olduğumuz varsayımı altında; Y değişkeninin bağımlı, kendi gecikmeli ve $\mathrm{X}$ değişkeninin gecikmeli değerlerinin bağımsız değişken olduğu model, Y değişkenin bağımlı, kendi gecikmeli değerinin bağımsız değişken olduğu modelden daha yüksek öngörü başarısı sağlıyorsa $X_{t}{ }^{6}$ deki değişmeler $\mathrm{Y}_{\mathrm{t}}$ ' nin Granger nedenidir denir (Altıntaş vd., 2008) .

Bu çalışmada da dış ticaret (İthalat ve İhracat) ile ekonomik büyüme (GSMH) arasındaki ilişkisinin araştırılması amacıyla “Granger Nedensellik Analizi”nden yararlanılmıştır. Granger nedensellik testi aşağıdaki iki regresyonun tahmini ile yapılmaktadır (Bilgili vd., 2007: 140-141) .

$$
\begin{gathered}
Y_{t}=\sum_{i=1}^{m} \alpha_{i} X_{t-i}+\sum_{j=1}^{n} \beta_{j} Y_{t-j}+u_{1 t} \\
X_{t}=\sum_{i=1}^{m} \lambda_{i} Y_{t-i}+\sum_{j=1}^{n} \delta_{j} X_{t-j}+u_{2 t}
\end{gathered}
$$

Burada, $\mathrm{u}_{1 \mathrm{t}}$ ve $\mathrm{u}_{2 \mathrm{t}}$ hata terimlerinin aralarında korelasyon olmadığ

\section{Granger Nedensellik Analizi: Dış Ticaret-- Büyüme İlişkisi}

Bu bölümde İran'ın ithalat ve ihracatının Gayrisafi Yurtiçi Hâsıla'sı (GSYH) içindeki payı ile ekonomik büyümesi arasında bir nedensellik ilişkisinin olup olmadığı araştırılmıştır. Bu amaçla İran için 1969-2014 dönemine ilişkin yıllık verilerin yüzde olarak ithalatın GSYH içinde payı (İTHALAT_IRN) ve yüzde olarak ihracatın GSYH içinde payı (İHRACAT_IRN) ile ekonomik 
büyüme göstergesi olan GSYH'deki yüzde değişim (GSYH_IRN) değişkenleri alınmıştır. Ayrıca analizde kullanılan veriler World Bank’tan alınmıştır. Çalışmada İran için kullanılan serilere ilişkin özet istatistikleri Tablo 3'de belirtilmiştir.

Tablo 3.

İran için Kullanılan Serilere İlişkin Özet İstatistikler

\begin{tabular}{cccc}
\hline \hline & GDP_IRN & IMP_IRN & EXP_IRN \\
\hline Ortalama & 3,22 & 20,99 & 21,72 \\
Standart Hata & 1,26 & 0,81 & 1,32 \\
Ortanca & 3,52 & 21,13 & 22,65 \\
S. Sapma & 8,54 & 5,48 & 8,97 \\
Basıklık & 0,88 & 0,14 & 0,48 \\
Çarpıklık & $-0,37$ & 0,12 & 0,42 \\
Aralık & 44,77 & 26,65 & 43,64 \\
En Küçük & $-21,60$ & 8,73 & 3,73 \\
En Büyük & 23,17 & 35,38 & 47,37 \\
\hline
\end{tabular}

Tablo 3'den görüldüğü üzere İran'ın ekonomik büyümesi ele alınan dönemde ortalama \% 3,22 değerine, ithalatının GSYH içindeki payı ortalama \% 20,99 değerine ve ihracatın GSYH içindeki payı ortalama \% 21,72 değerine sahip olmuştur. İran'ın ekonomisi ilgili dönemde \% 21,6 küçülme ile \% 23,17 büyüme arasında değişkenlik gösterirken, İTHALAT_IRN değişkeni \% 8,73 ile \% 35,38 arasında ve İHRACAT_IRN değişskeni \% 3,73 ile \% 47,37 arasında değişkenlik göstermektedir.

Değişkenlerin çarpıklık ve basıklık değerlerine bakıldığında ITHALAT_IRN ile IHHRACAT_IRN değişkenlerin hafif sağa çarpık bir yapıda olduğu söylenebilir. GDP_IRN değişkeninin ise -0.37 çarpıklık katsayısı ile hafif sola çarpık bir yapıda olduğu söylenebilir. Bunun yanında basıklık değerleri Tablo 3'de normal dağılımın basıklık değeri olan 3 ile farkı olarak gösterilmektedir. İran için kullanılan tüm değişkenlerin basıklık katsayısının pozitif olmasından kaynaklı normal dağılıma göre daha sivri bir yapıda olduğu söylenebilir.

\subsection{Birim Kök Testleri}

Çalışmada değişkenler arasındaki ilişkinin incelenmesi amacıyla öncelikle serilerin birim köke sahip olup olmadığı bir başka söylemle durağan olup olmadığı araştırılmıştır. Bu amaçla 
öncelikle Dickey-Fuller (1979) tarafından geliştirilen Genişletilmiş Dickey Fuller Testi (ADF) kullanılmıştır.

ADF testini açıklamak için $\varepsilon_{t}$ beyaz gürültü hata terimi olmak üzere Y serisinin aşağıdaki gibi modellendiğini varsayalım (Uğurlu,2009) .

$$
\Delta Y_{t}=\alpha_{0}+\beta t+\rho Y_{t-1}+\sum_{i=1}^{k} \beta_{i} \Delta Y_{t-i}+\varepsilon_{t}
$$

Kullanılan hipotez ve test istatistiği aşağıda verilmiştir.

$$
\begin{gathered}
H_{0}: \rho=0 \text { Seri durağan değildir. Serinin birim kökü vardır. } \\
H_{a}: \rho<0 \quad \text { Seri durağandır. Serinin birim kök yoktur. }
\end{gathered}
$$

Uygulanan testte her bir değişken için 4 gecikmeye kadar gecikmeli değerleri kullanılan modellere sırasıyla eklenmiş ve Schwarz Bilgi Kriteri değerini en küçük yapan gecikme sayısı en uygun gecikmeli değer olarak belirlenmiş ve testin sonucu bu çerçevede değerlendirilmiştir. İran için kullanılan değişskenlere ilişkin test sonuçları Tablo 4'de belirtilmiştir.

Tablo 4.

ADF Testi Sonuçları

\begin{tabular}{llllll}
\hline \hline \multirow{2}{*}{ Değişken } & & Model & Gecikme Uzunluğu & t-istatistiği & p-değeri \\
& & & & \\
\hline GSYİH_IRN & Düzey & Sabitsiz ve Trendsiz & 0 & $-4,1402^{* * *}$ & 0,0001 \\
GSYİ_IRN & Düzey & Sabitli & 0 & $-4,3797^{* * *}$ & 0,0011 \\
GSYİ_IRN & Düzey & Sabitli ve Trendli & 1 & $-4,2980^{* * *}$ & 0,0074 \\
ITHALAT_IRN & Düzey & Sabitsiz ve Trendsiz & 0 & $-0,7493$ & 0,3862 \\
ITHALAT_IRN & Düzey & Sabitli & 0 & $-2,9039^{*}$ & 0,0528 \\
ITHALAT_IRN & Düzey & Sabitli ve Trendli & 0 & $-2,9305$ & 0,1631 \\
IHHRACAT_IRN & Düzey & Sabitsiz ve Trendsiz & 0 & $-0,5739$ & 0,4631 \\
IHRACAT_IRN & Düzey & Sabitli & 0 & $-1,9844$ & 0,2924 \\
IHRACAT_IRN & Düzey & Sabitli ve Trendli & 0 & $-1,9602$ & 0,6066 \\
IHHRACAT_IRN & İlk Fark & Sabitsiz ve Trendsiz & 0 & $-6,2286^{* * *}$ & 0,0000 \\
IHHRACAT_IRN & İlk Fark & Sabitli & 0 & $-6,1582^{* * *}$ & 0,0000 \\
IHHRACAT_IRN & İlk Fark & Sabitli ve Trendli & 0 & $-6,0829^{* * *}$ & 0,0000 \\
\hline
\end{tabular}

Not. ${ }^{* * *}$ ve $* *$ sırasıyla $\% 1$ ve $\% 5$ de boş hipotezin reddedildiğini göstermektedir. 
Tablo 4'de ADF testi sonuçları İran için kullanılan tüm değişkenlere ilişskin hem düzeyde hem de (düzeyde durağan değilse) ilk farkı alınarak

- Sabitsiz ve trendsiz

- Sabitli

- Sabitli ve trendli

modeller için verilmektedir. Buna göre GSYİH_IRN değişkeni için yapılan ADF testi sonucunda tüm modellerde boş hipotezin \%1 düzeyinde reddedildiği yani serinin durağan olduğu sonucuna varılmıştır. İTHALAT_IRN değişkeni için düzeyde sabitli \%10 anlamlılık düzeyinde reddedilmiş ve düzeyde durağan olduğu sonucuna varılmıştır. İHRACAT_IRN değişkeninin durağan olmadığı birinci farkta \%1 anlam düzeyinde durağanlaştı̆̆ı saptanmıştır.

Özet olarak İran için kullanılan değişkenlere ilişkin ADF test sonuçlarına göre GSYİH_IRN ve İTHALAT_IRN değişkenlerinin düzeyde durağan yani I(0) ve İHRACAT_IRN değişkeninin ise birinci derece entegre yani I(1) olduğu söylenir. Dolayısıyla Granger Nedensellik testinde bu değişkenin birinci sıra farkı-D(IHRACAT_IRN)- alınarak analiz gerçekleştirilmiştir.

Tablo 4'de belirtilen birim kök testlerinden elde edilen sonuçlara göre Granger nedensellik testinde kullanılacak değişkenler görüldüğü üzere GSYİH_IRN, İTHALAT_IRN ve $\triangle$ İHRACAT_IRN'dir. Granger Nedensellik testi aynı zamanda gecikme sayısına duyarlı bir testtir. $\mathrm{Bu}$ nedenle gecikme sayısının belirlenmesi amacıyla VAR modeli kurularak, VAR modelinin gecikme sayısı analizde kullanılmıştır.

\section{Tablo 5 .}

İran için Kullanılan Değişkenler ile Kurulan VAR Modeline İlişskin Uygun Gecikme Sayısı

\begin{tabular}{cccccc}
\hline \hline Gecikme Sayısı & LR & FPE & AIC & SC & HQ \\
\hline 0 & NA & 38071,2000 & 19,0608 & 19,1888 & 19,1067 \\
1 & 33,2473 & 23411,1300 & 18,5724 & $19,08429^{*}$ & 18,7561 \\
2 & 21,3978 & 19215,0100 & 18,3653 & 19,2611 & 18,6867 \\
3 & $24,61758^{*}$ & $13352,01^{*}$ & $17,97794^{*}$ & 19,2576 & $18,43707^{*}$ \\
4 & 8,7627 & 15807,8900 & 18,1025 & 19,7660 & 18,6993 \\
\hline
\end{tabular}


Tablo 5'de kurulacak VAR modeli için uygun gecikme sayıları olabilirlik oran (LR), nihai kestirim hataları (FPE), Akaike Bilgi Kriteri (AIC), Schwarz Bilgi Kriteri (SC) ve Hannan Quinn Bilgi Kriteri (HQ) değerlerine göre gösterilmektedir. Buna göre LR değeri en yüksek, FPE ve AIC ve HQ değerleri en küçük 3. gecikmede görüldüğünden kurulacak VAR modeline ilişkin gecikme değeri 3 olarak alınacaktır.

Granger Nedensellik analizi temelinde VAR modeline dayandığından bu analizde de gecikme sayısı 3 alınarak nedensellik analizi yapılmıştır. Sonuçlar Tablo 6' da belirtilmiştir.

\section{Tablo 6.}

İran için Kullanılan Değişkenler için Granger Nedensellik Analizi

\begin{tabular}{lcc}
\hline \hline Boş Hipotez & F-istatistiği & p-değeri \\
\hline İTHALAT_IRN, GSYİH_IRN'nın Granger Nedeni Değildir & 7,4713 & 0,0005 \\
GSYİH_IRN, İTHALAT_IRN'nın Granger Nedeni Değildir & 1,6311 & 0,1993 \\
& & \\
D(İHRACAT_IRN), GSYİH_IRN'nın Granger Nedeni Değildir & 3,7491 & 0,0195 \\
GSYİH_IRN, D(İHRACAT_IRN)'nın Granger Nedeni Değildir & 0,6629 & 0,5805 \\
\hline
\end{tabular}

Tablo 6'da verilen Granger Nedensellik analizi sonuçlarına göre;

- İTHALAT_IRN, GSYİH_IRN'nın Granger nedeni değildir boş hipotezi \%1 anlamlılık düzeyinde reddedilmiştir.

- GSYİH_IRN, İTHALAT_IRN'nın Granger Nedeni değildir boş hipotezi reddedilememiştir,

- D(İHRACAT_IRN), GSYİH_IRN'nın Granger Nedeni değildir boş hipotezi \%5 anlamlılık düzeyinde reddedilmiştir,

- GSYİH_IRN, D(İHRACAT_IRN)'nın Granger Nedeni değildir boş hipotezi reddedilememiştir.

Dolayısıyla ele alınan değişkenler arasında İTHALAT_IRN değişkeninden GSYİH_IRN değişkenine ve D(IHRACAT_IRN) değişkeninden GSYİH_IRN değişkenine tek yönlü Granger tipi nedensellik olduğu söylenir. Hem ihracatın hem de ithalatın büyümenin Granger nedeni olduğu sonucuna varılmıştır. GSYH'nın hem ihracatın hem de ithalatın nedeni olmadığı görülmüştür. 


\section{Sonuç ve değerlendirme}

Bu çalışmada önemli petrol rezervine sahip bir Ortadoğu ülkesi olan İran ele alınmıştır. Ülkede de başlıca gelir kaynağı petroldür. İran'ın ekonomik yapısı incelenmiş ve makroekonomik veriler yardımıyla ülke ekonomileri yorumlanmaya çalışılmıştır. İran'ın ekonomik büyümesinin dış ticaretine doğrudan ilişkili olup olmadığı sorusuna cevap aranmış ve bu sorunun cevabı çalışmanın ikinci bölümünde Granger nedensellik analizi kullanılarak cevaplandırılmıştır. Bunun için önce kullanılan değişkenlerin durağanlık düzeylerinin saptanması yoluna gidilmiştir. $\mathrm{Bu}$ amaçla durağanlık testlerinden en çok kullanılan test olan ADF testi kullanılmıştır. ADF test sonuçları ithalatın GSYH içindeki payı ve GSYH'deki yüzde değişim değişkenlerinin düzeyde durağan, ihracatın GSYH içindeki payı değişkeninin ise ilk farta durağan olduğunu göstermiştir. Durağan seriler ile yapılan Granger nedensellik testi sonucunda hem ithalatın büyümenin nedeni olduğu ve hem de ihracatın İran'ın ekonomik büyümesine neden olduğu sonucuna varılmıştır. Yapılan analiz sonucunda ülkenin dış ticaret performansının ekonomik büyümesine neden olduğu yönünde sonuçlar elde edilmiştir.

\section{Kaynakça}

Akal, M., Doğruyol, A., \& Bilişli, K. (2011). Şanghay işbirliği örgütü ve Türkiye-İran savunma harcamaları nedenselliği testi. Akademik Bakış Dergisi, 23, 1-15.

Akça, İ. (2013). Türkiye'nin dlş ticaretinde Ortadoğu'nun yeri ve önemi (2000-2010). Marmara Üniversitesi Ortadoğu Araştırmaları Enstitüsü, Ortadoğu İktisadı Anabilim Dalı, İstanbul.

Akıncı, M., Aktürk, E., \& Yılmaz, Ö. (2013). Petrol fiyatları ile ekonomik büyüme arasındaki ilişki: Opec ve petrol ithalatçısı ülkeler için zaman serisi analizi. Atatürk Üniversitesi Sosyal Bilimler Enstitüsü Dergisi, 1, 349-361.

Arısoy, İ. (2005). Wagner ve Keynes Hipotezleri çerçevesinde Türkiye'de kamu harcamaları ve ekonomik büyüme ilişkisi. Ç.Ü. Sosyal Bilimler Enstitüsü Dergisi, 14(2), 63-80.

Altıntaş, M., Güvercin, D., \& Uğurlu, E. (2008). Geçiş ekonomilerinde doğrudan yabancı sermaye yatırımları ve ekonomik büyüme ilişkisi. Ekonomik Yaklaşım, 19(Özel Sayı), 17-32.

Berber, S. (2013). İran'ın ekonomi politikası, yaptırımların etkisi ve ikilemleri. Bilge Strateji, 5(9), 61-84. 
Bilgili, F., Düzgün, R., \& Uğurlu, E. (2007). Büyüme, doğrudan yabanc1 sermaye yatırımları ve yurtiçi yatırımlar arasındaki etkileşim. Erciyes Üniversitesi Sosyal Bilimler Enstitüsü Dergisi, 23 (2), 127-152.

Dickey, D. A., \& Fuller, W. A. (1979). Distribution of the estimators for autoregressive time series with a unit root. Journal of the American Statistical Association, 74, 427-431.

Dickey, D. A., \& Fuller, W. A. (1981). Likelihood ratio statistics for autoregressive time series with a unit root. Econometrica, 49, 1057-72.

Direnizci, A. (2005). 1990-2004 yılları arasında Türkiye ile Ortadoğu ülkelerinin ekonomik ilişkileri. Gaziantep Üniversitesi Sosyal Bilimler Enstitüsü Yayınlanmamış Yüksek Lisans Tezi.

Dural, E. (2007). Türkiye’nin Orta Doğu Politikası. Osman Gazi Üniversitesi Sosyal Bilimler Enstitüsü Yayınlanmamış Yüksek Lisans Tezi.

Enders, W. (1995). Applied Econometric Time Series. New York: John Wiley \& Sons, Inc.

Genç, M. C., Değer, M. K. \& Berber, M. (2010). Beşeri sermaye, ihracat ve ekonomik büyüme: Türkiye ekonomisi üzerine nedensellik analizi. Bilgi Ekonomisi ve Yönetimi Dergisi, V(I), 29-41.

İran İslam Cumhuriyeti Ülke Raporu, (2008). Konya Ticaret Odası Etüt Araştırma Servisi. Alınan yer http://www.kto.org.tr/dosya/rapor/iran.pdf (08.05.2008).

Dış Ticaret Müsteşarlığı (2006). İran'ın Ekonomik Durumu. İhracatı Geliştirme Etüt Merkezi Periyodik Yayınları. Alınan yer http:/www.expotim.com/ulkebilgileri.asp?ID=iran (02.03.2008).

Tahran Büyükelçiliği Ticaret Müşavirliği (2007). İran’ın Genel Ekonomik Durumu ve Türkiye ile Ekonomik ve Ticari İlişkileri. Alınan yer $\underline{\text { www.musavirlikler.gov.tr/altdetay.cfm?AltAlanID }=368 \& \text { dil }=\text { TR\&ulke }=\mathrm{IR}}(02.03 .2008)$.

İran Ülke Raporu (2007). Makine İhracatçıları Birliği. Alınan yer http://www.makinebirlik.com/tr/sanal-kutuphane/ulke-raporlari/iran-ulke-raporu (20.03.2017).

Lewis, B. (1964). Orta şarkın hüviyeti. Ankara Üniversitesi İlahiyat Fakültesi Dergisi, XII, 41. 
Mazman İ. Ü. (2008). Türkiye'nin Ortadoğu Ülkeleri ile ekonomik ve ticari ilişkileri üzerine bir değerlendirme. Cumhuriyet Üniversitesi Sosyal Bilimler Enstitüsü, İktisat Anabilim Dalı İktisadi Gelişme ve Uluslararası İktisat Bilim Dalı Yüksek Lisans Tezi.

Oktayer, N., \& Susam, N. (2008). Kamu harcamaları-ekonomik büyüme ilişkisi: 1970-2005 y1lları Türkiye örneği. Atatürk Üniversitesi İktisadi ve İdari Bilimler Dergisi, 22(1), 145-164.

Turan, K., \& Özarı, Ç. (2015). Türkiye'de işsizlik sorunu: Bölgesel karşılaştırmalar, KSBD, 7, 155 177.

Turan, K., Özarı, Ç., \& Demir, E. (2016). Kümeleme analizi ile Türkiye ve Ortadoğu ülkelerinin ekonomik göstergeler açısından karşılaştırılması, İstanbul Aydın Üniversitesi Dergisi, 29, 143-165.

Uğurlu, E. (2009). Real exchange rate and economic growth: Turkey. Manas Journal of Social Sciences, 22, 191-212.

Valadkhani, A. (2003). The causes of unemployment in Iran: An empirical investigation. Faculty of Commerce-Papers, Alınan yer http://ro.uow.edu.au/commpapers/390.

Yardımcıŏlu, F., \& Gülmez, A. (2013). OPEC ülkelerinde Hollanda hastalığı: Petrol fiyatları ve ekonomik büyüme ilişkisinin ekonometrik bir analizi. Sosyo-Ekonomi Dergisi, 1, 117 140.

Zamanzadeh, A., \& Mehrara, M. (2011). Testing twin deficits hypothesis in Iran. Interdisciplinary Journal of Research in Business, 1(9), 7- 